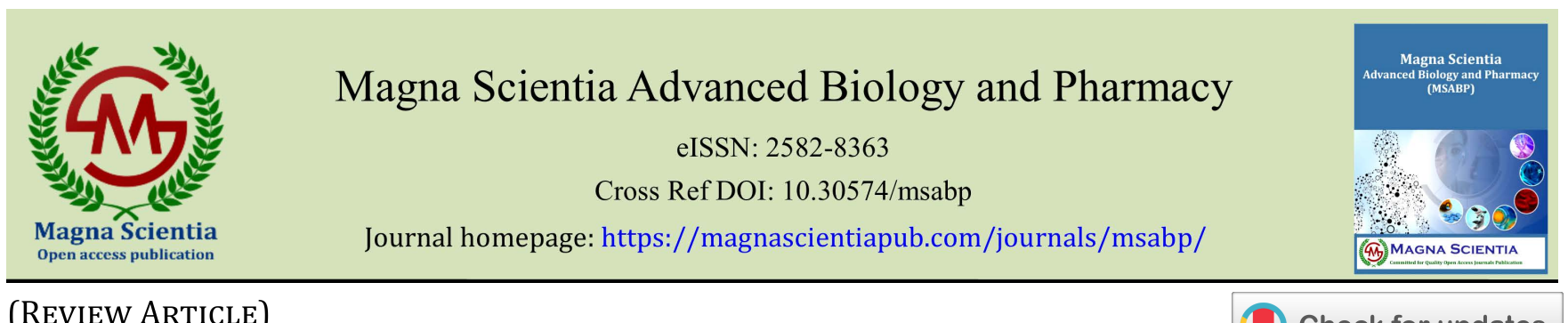

(REVIEW ARTICLE)

\title{
Two worst pandemics- Spanish Flu and COVID-19: A review
}

\author{
Varsha Dhurvey*, Payal Ramteke, Rakhi Sawan and Shikha Sethiya \\ Department of Zoology, RTM Nagpur University, Nagpur, India.
}

Magna Scientia Advanced Biology and Pharmacy, 2021, 04(01), 001-012

Publication history: Received on 06 October 2021; revised on 08 November 2021; accepted on 10 November 2021

Article DOI: https://doi.org/10.30574/msabp.2021.4.1.0050

\begin{abstract}
1918 Spanish flu and COVID-19 can be considered as most hazardous pandemics earth has ever witnessed. They are results of what mayhems an organism not even visible with naked eye can cause. Causative agent for both the diseases is a virus but, they are not same. 1918 Spanish flu gave major indications that it has the existence of the new strain of flu and lasted for longer duration affecting lives in various ways. COVID-19 is again an indication of another emerging worst pandemic. Here, we have reviewed the overall factors that contributed to the severity of these two pandemics and comparison of the same. The main motive of this paper is to put together, compare and analyze versatility of both the pandemics and to discuss implications of the same.
\end{abstract}

Keywords: Pandemic; 1918 Spanish flu; COVID-19; Impacts; Comparison

\section{Introduction}

History suggests that, pandemics have caused widespread illness infecting millions of people worldwide, causing thousands of deaths. Feinleib [1] reviewed that pandemic can be defined as, an epidemic that occurs globally, or over a very extensive area crossing international boundaries and generally influencing large number of people. There are three criteria a virus must fulfill to cause pandemic: 1) no precedent immunity against it in population 2) the potential to cause illness in humans 3) contagious between humans [2]. All the three criteria mentioned above, for a virus to cause pandemic, are fulfilled by H1N1 virus and novel corona virus responsible for causing 1918 influenza and COVID-19 pandemic respectively [3]. Both the 1918 influenza which is referred as mother of all pandemics by Taubenberger and Morens [4] as well as COVID-19 referred as "once in a century health crisis", by WHO [5], has led to ruinous and scarring impacts on health and lives of people with the outcomes capable of remaining irreversible for a decennary or more. This review aims at gathering the essential information and to summarize findings on origin, epidemiology, clinical features, treatments and comparisons between Spanish flu and COVID-19.

\section{The 1918 Spanish flu}

In the military forts of the United States in March 1918 the "first wave" of the 1918 pandemic seems to arise [6]. The disease spread gradually in Europe. Reports about the ongoing spread of the disease were restricted due to wartime censorship by various countries. Spain being a neutral country conveyed all the horrid details of this pandemic and hence the disease came to known as the "Spanish flu" [7]. The virus was introduced into the human host before 1915 and is thought to have an avian ancestry from an unknown source which took place in three waves. Pandemic was caused by Influenza A virus of the H1N1 subtype [8]. It spread all-over the world in one deadly wave after another which evoked the word "flu". Approximately 1.8 billion were infected and more than 50 million died within short stretch of time. It is still unresolved what factor gave the 1918 virus the unmatched ability to pave way to successive pandemic

\footnotetext{
${ }^{*}$ Corresponding author: Varsha Dhurvey

Department of Zoology, RTM Nagpur University, Nagpur, India.
}

Copyright (@ 2021 Author(s) retain the copyright of this article. This article is published under the terms of the Creative Commons Attribution Liscense 4.0. 
waves. The effect of the pandemic is that the virus finds comparatively easy to enter into the host's respiratory system and replicates [9].

\subsection{Origin and Epidemiology}

Spanish flu pandemic was seemingly first originated in early March of 1918 [10]. It is still uncertain that where this pandemic began. Palese [11] reviewed the book by John M. Barry, which hypothesized that 1918 influenza pandemic is most likely to be originated in Haskell County, Kansas. Some researchers suggest that, it was originated in Asia, while others suggest it was originated in China or Vietnam, crossing U.S. [12]. According to Oxford [13], influenza virus first emerged in a British Army post in France.

The first wave of pandemic was mild but, the virus transmitted very rapidly through Western Europe and it reached Poland by July, 1918 and after that became more fatal by August, 1918. By winter of 1918, third wave arrived and reached more lethal stage by the spring, leading to 40-50 million deaths globally including 12.5 million in India and 550,000 in United States [10].

\subsection{Virology}

The molecular basis of each pathogen's structural properties, including infectivity, cell tropism, replication, immunogenicity, pathogenicity, and transmissibility is necessary to combat infectious diseases. Many pathogenic studies performed in animal models, showed both "gain-of-function" and "loss-of-function" using chimeric influenza viruses by carrying one or more 1918 viral genes of interest, expressed on less pathogenic viral "reference" backgrounds [14]. Several reverse genetics experiments indicated that the 1918 influenza virus exerts high pathogenicity and an interplay between different virulence factors, where a crucial role was played by the proteins which were encrypted by the polymerase gene and viral hemagglutinin (HA) segments $[14,15,16,17]$.

Influenza virus is usually spherical and at times can be referred as virion. Seventy- five percent proteins, one fourth percent ribonucleic acids (RNA) six and-a-half percent carbohydrate and eighteen percent lipids whole together make its structure. RNA is a genetic material present in nucleocaspid. It is related to nucleoprotein (NP) antigen which is used in further classification of influenza viruses into types A, B and C [18]. Nucleocaspid is surrounded by bilayers, an inner protein and an outer lipid membrane. Of which outer membrane have two types of spike-like projections namely hemagglutinin $(\mathrm{H})$ and neuraminidase $(\mathrm{N})$ which are glycoproteins [19]. This further indicates the fact that there are other minor protein substances present in the virus. To show its effect influenza virus enters into the human host cell to reproduce [18].

\subsection{Transmission}

Rate of transmission of influenza virus was observed to be very rapid. Transmission of virus was facilitated by wildly crowded military camps [20]. According to Britannica [10] number of cases went from 1 to 6,674 within six days at Camp Devens, Massachusetts, U.S. There are three widely accepted routes for human influenza virus transmission: 1 ) Droplets: Droplets released from mouth and nose, settle on mucus surface of upper respiratory tract as they are very large to reach lungs. 2) Aerosols: these are droplets nuclei that can also settle on mucus surface of upper respiratory tract but are also capable to reach lower respiratory tract as they are minute in size. 3) Person-person transmission: This occurs via close contact with infected person or contact with contaminated objects or surfaces [21].

\subsection{Diagnosis}

During 1918, there were no diagnostic tests available that could help in diagnosis of the disease. Even doctors were unaware about existence of influenza virus. At that time, it was believed by health experts that, 1918 pandemic was caused by a bacterium called "Pfeiffer's bacillus," which is now known as Haemophilus influenzae [22].

\subsection{Clinical Manifestations}

The initial signs and symptoms of Spanish influenza usually begin with cold, with sneezing and coughing with sudden attack. Canadian Medical Association published a report describing a typical case of influenza. According to that it began with instant weakness, pain and chills. Quantity of blood was also seen during coughing. Cyanosed face and fingers were also seen [23]. A medical report showed three distinct forms in which the influenza presented itself, though these forms co-presented in the majority of cases: (i) Nervous influenza: Very slow, intense cephalalgia, pain in eye orbits, joints and muscles. Symptoms ceased, strong dry cough accompanied by rubelliform and skin rash on arms, wrists and chest. Also, urticaria was observed. (ii) Pulmonary influenza: Shows pharyngeal, laryngeal and pulmonary symptoms. This form was deadliest of all. (iii) Gastric form: Characterized by digestive disease, vomiting diarrhoea, etc. [24]. 
A violent viral pneumonia also caused deaths often with either massive acute pulmonary haemorrhage or pulmonary edema. The disease course was less than 5 days [25].

\subsection{Treatment}

Earlier there were no such effective vaccines, antiviral drugs, or antibiotics available before the second half of the twentieth century as it was novel virus. The main strategy for treatment of influenza virus disease in 1918 was limited to supportive care [26]. So initially people were relying on the available remedies to reduce symptoms and the severity of the disease which included acetylsalicylic acid for reducing pain, fever or inflammation, anti-malarial drug such as quinine, ammonia, few drops of turpentine, water with salt, topical rubs for pain relief, inhaled substances for nasal congestion, and Bovril which is a thick, salty meat extract. Serum of patients which recovered from disease was collected by some physicians and this convalescent serum was injected into patients with active infection and according to metaanalysis of publications reporting this strategy, the patients which injected convalescent serum may have lower risk of death [20].

\subsection{Vaccines}

In attempts to control the spread of influenza virus, physicians developed and recommended non-standardized vaccines, as the medical community believed that influenza pandemic was caused by bacillus Haemophilus influenzae(named later), these vaccines were primarily recommended for protection against Pfeiffer's bacillus[20]. Firstly in 1943, killed vaccine was developed which was effective. Later from 1941, Fleming's penicillin was used to treat bacterial pneumonia. In 1963, amantadine came which was active against influenza and was tested in vivo, showing effectiveness in reducing the severity of symptoms and the length of the disease. In 1989, neuraminidase inhibitor, zanamivir (Relenza) came into the market. Later in 1993, antiviral drug called rimantadine was introduced and was reported for having severe side effects. Also, another neuraminidase inhibitor such as oseltamivir (Tamiflu), were developed commercially in 2005 and 2006 [26].

\subsection{Post-Influenza Manifestations}

Survivors of Spanish flu pandemic were reported to deal with sleeping disorders, depressive disorder, distractibility, hypotension and tiredness in daily life for a long time till several years, even after recovering from the disease [27]. Hepatitis, ear illnesses, deafness, blindness, and baldness were other after-effects that have been noticed in the persons linked to Spanish Influenza. After recovery from Spanish flu influenza, some patients have been reported to experience cardiac abnormalities, lung tuberculosis and kidney disorders in later life [28].

\section{COVID-19}

In December 2019, COVID-19 began with a sign of atypical pneumonia in Wuhan, Hubei, China [29]. Severe acute respiratory syndrome corona virus 2 (SARS-CoV-2) is found to be causative agent of COVID-19 pandemic [30]. Corona virus is a large family of viruses belonging to Coronaviridae family and order Nidovirales which have potential to cause illness in animals and humans [31]. Corona viruses can be divided into 4 genera- alpha $(\alpha)$, beta $(\beta)$, gamma $(\gamma)$ and delta $(\delta)$ but only alpha and beta have been known to be infectious to human beings [32]. It was observed that novel corona virus has similar symptoms to that of SARS-CoV in 2012 and both of them have same receptor- angiotensin converting enzyme 2 (ACE-2), therefore it was named as SARS-CoV-2 by WHO in February, 2020 [33]. Owing to devastating impacts of COVID-19 disease, WHO in January, 2020, declared it as Public Health Emergency of International concern [29].

\subsection{Origin and Epidemiology}

Human patients of COVID-19 were first found in December 2019, in Wuhan city of China, and most of the patients were reported to be stall owners, market employees and regular visitors of local Huanan Seafood wet market [34] and hence, market was shut down on 1st January, 2020 [35]. To identify origin of infection, a deep sequencing analysis of lower respiratory tract was carried out and samples showed that, the virus responsible for causing atypical pneumonia was novel SARS-CoV-2 and disease caused by it was named as COVID-19 on 11th February, 2020 by WHO Director-General, Dr. Tedros Adhanom Ghebreyesus [36]. The analysis of genetic sequences of SARS-CoV-2 from initial patients and those from later cases from china as well as other countries suggests that, SARS-CoV-2 is not artificial or lab-constructed virus but has an ecological origin in bat population [34]. Sheahan et al., [32] suggested that all corona viruses that infect humans are probably originated as zoonotic pathogens that have jumped from non-human animals to humans and number of corona virus pathogens causing SARS and MERS are observed to be present in bat reservoir species. Thus, it is assumed that source of origin of pandemic could be bats because the full genetic analysis points that coronavirus shares $88 \%$ sequence identity to Bat-CoV which lead to SARS, but it is found to be more distant [35, 37]. 
COVID-19 outbreak spread very rapidly and first case outside China was found on 13th January, 2020 in Bangkok, Thailand [35]. Within first six weeks, a large number of cases were found in more than 37 countries including USA, Japan, Iran and South Korea [38] and till March, 2020, it reached South-East Asia, affecting large number of people [39] and then, on 11th March, 2020, WHO declared COVID-19 as pandemic when it reached 114 countries including 118,000 cases and more than 4000 deaths [36]. According to weekly epidemiological update on COVID-19 by WHO, 14 September, 2021, was reported with 4 million new cases globally which represents first substantial reduction in weekly cases, whereas according to report on October 19, 2021, number of new cases decreased to 2.7 million [40, 41]. Currently, as of 20 October, 2021, globally, 241,411,380 confirmed cases and 4,912,112 deaths are recorded with 457,013 new cases and 8093 new deaths [42].

\subsection{Virology}

SARS-CoV-2 is microscopic, with diameter ranging from $60-140 \mathrm{~nm}$ and is enveloped with round or elliptical particles which are usually polymorphic [43]. SARS-CoV-2 virus is consists of 9-12 $\mathrm{nm}$ long crown like spikes on its surface [37]. The envelope encapsulates circular nucleocaspid proteins, inside which genome of corona virus i.e. large positive single stranded ribonucleic acid, containing 29891 nucleotides and 9860 amino acids [44] with size ranging from 26 to 32 kilobases in length, is present [43]. Genome of corona virus contains 10 open reading frames (ORF) with first ORF consisting of two thirds of viral RNA which codes for polyprotein $1 \mathrm{a}$, polyprotein $1 \mathrm{~b}$ and 1-16 non-structural proteins; whereas other ORFs encode for structural proteins like: 1) spike (S) protein having 2 subunits S1 and S2 that assist receptor binding and membrane fusion respectively 2) $\mathrm{N}$ protein which intensifies the viral entry 3) E protein which advances virion formation and pathogenicity and 4) M protein that structures ribonucleoproteins and provoke inflammatory response in host [44].

SARS-CoV-2 attacks epithelial cells of naso-bronchial region via spike proteins by binding to ACE-2 receptor, a membrane bound amino peptidase present between lungs and heart [45], and type 2 transmembrane serine protease (TMPRS S2) breaks down ACE-2, encouraging viral uptake, which results into activation of SARS-CoV-2 protein and mediates entry of virus in host cell [46]. While entering new human host, SARS-CoV-2 undergoes mutation forming mutant variants and several such variants are identified from onset of pandemic till now but, only few are considered as variants of concern. According to epidemiological update by WHO on June 22, 2021, SARS-CoV-2 variants found from start of pandemic which are considered as variants of concern are: Alpha (B.1.1.7), Beta (B.1.351), Gamma (P.1) and Delta (B.1.617.2) [47].

\subsection{Transmission}

During onset of pandemic, a relation between origin of SARS-CoV-2 and Huanan market in Wuhan, China was observed [48] but findings suggest that there is a possibility that, at first SARS-CoV-2 was hosted by bat and it was passed on to human population through pangolin or any other wild animals, which are sold at wet market but, later it was spread potentially by person-person transmission [37]. SARS-CoV-2 can be transmitted via: 1) symptomatic carriers during close contact, droplets expelled from mouth and nose during breathing, talking, coughing and sneezing or through contact with infected surfaces 2) pre-symptomatic carriers, as during incubation period virus can be potentially transmitted 3) asymptomatic carriers, as even though they do not show symptoms but can be severely infected and are capable of transmission [49]. Chinese researchers observed SARS-CoV-2 in excreta of COVID positive patient, pointing the possibility of faeco-oral transmission [48]. Also, one of the studies showed positive results for COVID-19 on RTPCR in conjunctival swab, indicating the potential of transmission via eyes [35]. Li et al., [50] revealed that, a woman with SARS-CoV-2 infection delivered a baby, during her 35th week of pregnancy, which was tested negative for SARS-CoV-2 infection which suggests that transmission of virus from mother to child does not occurs.

\subsection{Diagnosis}

According to the recommendations issued by Centre of Disease Control and Prevention and World Health Organization, regarding the laboratory safety while diagnosis of corona virus suspected population specimens, the tests should be carried out in biosafety cabinets if there is possibility of splashes or generation of droplets or aerosols and only BL-3 laboratories should be used for isolation of virus [38].

The diagnosis for SARS-CoV-2 is done by using RTPCR, where a consensus E-region of beta corona virus or other specific regions like RdRp or N- region are targeted [35]. It is observed to show high false-negative test result rate in $27 \%-67 \%$ of infected people as it depends upon quality and timing of testing [46]. In addition to RTPCR, radiological examinations such as thin-slice chest CT as well as chest X-ray are used [35, 37]. Specimens for diagnosis of SARS-CoV-2 are collected in the form of sputum, branchioalveolar lavage fluid, nasopharyngeal swabs and oropharyngeal swabs [46]. According to Vieira et al., [48], SARS-CoV-2 can also be isolated from feces of infected person. Also, several serological assays such 
as point-of-care assay and high throughput enzyme immunoassay can also be used in diagnosis but variation may be found in their performance, precision and validity [46].

\subsection{Clinical Manifestations}

Symptoms of COVID-19 are highly variable where the severity ranges from, asymptomatic to lethal [36]. The average incubation period of SARS-CoV-2 infection is 5.6 days [51] and period of active monitoring and development of symptoms is 14 days [52]. Initial symptoms during the onset of COVID-19 outbreak were recorded to be fever, dry cough, muscle pain, fatigue, shortness of breath or dyspnea and sputum production which were more common whereas, less common symptoms include nausea, vomiting, stomach-ache, diarrhoea, haemoptysis (coughing of blood from respiratory tract), pharyngitis and nasal congestion [48]. Other common symptoms include partial (anosmia) or total (hyposmia) loss of smell and partial (hypogeusia) or total (ageusia) loss of taste, which was considered as one of the characteristic feature of SARS-CoV-2 infection [53]. CT scans during initial mild pneumonia showed small, sub pleural, unilateral or bilateral frosted glass opacities in lower lobes which lead to complicated paving pattern and further consolidation [43]. A few neurological symptoms which include headache, dizziness, impaired balance and coordination, cerebral apoplexy, seizure disorder, visual impairment, nerve pain [33] and also, ocular symptoms such as conjunctivitis, epiphora (tear flow), eye irritation and conjunctival hyperemia [48] were observed in patients in later stages. After a week of appearance of symptoms, patients with severe infection may feel tightness in chest and shortness of breath [54].

According to available data, elderly population with more than or about 60 years of age and those with poor immunity with pre-existing diabetes, cardiovascular and respiratory conditions, malignancy, kidney and liver diseases are at more risk for SARS-CoV-2 infection than that of children [43] and are more susceptible to respiratory failure owing to severe alveolar damage [37]. Patients with fatal respiratory disease of corona virus may develop bilateral pneumonia, acute respiratory distress syndrome (ARDS) which may worsen in short period of time causing multiple organ failure, leading to death [45].

\subsection{Treatment}

During onset of pandemic, limited treatments were available to decrease rate of disease and mortality due to COVID-19 [55] but tremendous efforts of clinical researchers from all around the world resulted into availability variety of therapeutic options [47]. Initially, the focus was on providing symptomatic and supportive care, maintaining vitals, oxygen level and blood pressure and treating severe symptoms [35]. In comparison to onset of pandemic, now a considerable number of therapeutic options for controlling the disease are available some of them include: antiviral drugs such as ramdesivir; combination therapy of lopinavir-ritonavir also, hydroxychloroquine and chloroquine [47], $\beta$-D-N4-hydroxycytidine [33], ivermectin [55] are recommended. In addition to this, convalescent plasma therapy for patients with severe condition such as ARDS, can be used [48]. Anti-SARS-CoV-2 monoclonal antibodies such as Casirivimab, Imdevimab, Bamlanivimab, Etesevimab, Sotrovimab [47]; anti-inflammatory drugs such as dexamethasone and statins; immunomodulation agents such as tocilizumab, sarilumab, anakinra, ruxolitinib, baricitinib; anticoagulants like heparin and antibiotics like tyrosinekinase inhibitors are also used in management of COVID-19 symptoms and treatment [46]. In China, some of the traditional medicines such as decodation of Qing Fei Pai Du that include: Ephedra herba, Gypsum fibrosum, Pinelliae rhizoma, Auranti fructus immaturus and Zingiberi rhizome recen were used and was advised by state administration of Chinese medicine on 6th February, 2020, as it had been observed to be $90 \%$ effective in treatment of SARS-CoV-2 [43].

\subsection{Vaccines}

The vaccines generally require years of research and clinical trials, before reaching to clinics but, in order reduce the burden of increasing mortality rate, researchers are working continuously to develop safe and effective vaccine against SARS-CoV-2 [56]. As of September 28, 2021, a total of 6,136,962,861 vaccine doses have been recorded to be administered worldwide [42]. 
Table 1 Some leading vaccines against SARS-CoV-2 virus [56]

\begin{tabular}{|c|c|c|c|c|c|}
\hline $\begin{array}{l}\text { Sr. } \\
\text { No. }\end{array}$ & Vaccine name & Developer & How it works & Status & Doses \\
\hline 1. & $\begin{array}{l}\text { Comirnaty/ } \\
\text { BNT162b2 }\end{array}$ & $\begin{array}{l}\text { Pfizer } \\
\text { (Germany) }\end{array}$ & mRNA & $\begin{array}{l}\text { Approved in U.S. and few other } \\
\text { countries and authorized for } \\
\text { emergency use in several } \\
\text { countries. }\end{array}$ & $\begin{array}{l}2 \text { doses } 3 \\
\text { weeks } \\
\text { apart }\end{array}$ \\
\hline 2. & $\begin{array}{l}\text { Spikevax or } \\
\text { Mrna-1273 }\end{array}$ & $\begin{array}{l}\text { Moderna } \\
\text { (Boston) }\end{array}$ & mRNA & $\begin{array}{l}\text { Approved in Switzerland, } \\
\text { Emergency use in U.S. and other } \\
\text { countries }\end{array}$ & $\begin{array}{l}2 \text { doses } 4 \\
\text { weeks } \\
\text { apart }\end{array}$ \\
\hline 3. & $\begin{array}{l}\text { Vaxzevria/ } \\
\text { AZD1222 or } \\
\text { Covishield in } \\
\text { India }\end{array}$ & $\begin{array}{l}\text { Oxford university } \\
\text { and AstraZeneca }\end{array}$ & Adenovirus & $\begin{array}{l}\text { Approved in } \\
\text { Emergency use } \\
\text { countries. }\end{array}$ & 2 doses \\
\hline 4. & Ad26.CoV.S & $\begin{array}{l}\text { Johnson } \quad \& \\
\text { Johnson }\end{array}$ & Adenovirus26 & $\begin{array}{l}\text { Authorized for emergency use in } \\
\text { U.S. and other countries. }\end{array}$ & 1 dose \\
\hline 5. & $\begin{array}{l}\text { Sputnik-V/ } \\
\text { Gam-Covid-Vac }\end{array}$ & Gamaleya, Russia & $\begin{array}{l}\text { Adenovirus Ad5 } \\
\text { \& Ad26 }\end{array}$ & $\begin{array}{l}\text { Authorized for emergency use in } \\
\text { Russia and several other } \\
\text { countries. }\end{array}$ & $\begin{array}{l}2 \text { doses } 3 \\
\text { weeks } \\
\text { apart }\end{array}$ \\
\hline 6. & NVX-CoV2327 & Novavax & Protein & In phase 3 & \\
\hline 7. & BBIBP-CorV & Sinopharm, China & $\begin{array}{l}\text { Inactivated } \\
\text { virus }\end{array}$ & $\begin{array}{l}\text { Approved in China, U.A.E and } \\
\text { Bahrain and for emergency use } \\
\text { in other countries. }\end{array}$ & $\begin{array}{l}2 \text { doss } 3 \\
\text { weeks } \\
\text { apart }\end{array}$ \\
\hline 8. & CoronaVac & Sinovac, China & $\begin{array}{l}\text { Inactivated } \\
\text { virus }\end{array}$ & $\begin{array}{l}\text { Approved in China, Emergency } \\
\text { use in other countries }\end{array}$ & $\begin{array}{l}2 \text { doses } 2 \\
\text { weeks } \\
\text { apart }\end{array}$ \\
\hline 9. & $\begin{array}{l}\text { Covaxin/ } \\
\text { BBVI522 }\end{array}$ & $\begin{array}{l}\text { Bharat biotech, } \\
\text { India }\end{array}$ & $\begin{array}{l}\text { Inactivated } \\
\text { virus }\end{array}$ & $\begin{array}{l}\text { Emergency use in India and } \\
\text { other countries. }\end{array}$ & $\begin{array}{l}2 \text { doses } 4 \\
\text { weeks } \\
\text { apart }\end{array}$ \\
\hline
\end{tabular}

\section{Post-COVID Manifestations}

Atypical clinical parameters or symptoms were observed in patients of COVID-19 infection and they do not succeed to return to normal condition, are considered as abiding effects of the disease [57]. Some of such symptoms observed are as follows:

- Neurological abnormalities such as headache, complete loss of taste and smell, dizziness [58], loss of memory, thinking ability and decision making, obsessive compulsive disorder, generalized anxiety disorder, attention deficit hyperactivity disorder, depression [57] as well as in a case multiple sclerosis and acute myelitis that may affect cervical spinal cord were observed [39].

- Pulmonary manifestations such as reduced pulmonary diffusing capacity, cough, chest tightness and decreased respiratory muscle capacity were observed in a few patients after 3 months of recovery from COVID-19 [58].

- Cardiovascular manifestations such as cardiac arrhythmia and myocardial inflammation as well other symptoms such as hair loss and joint pain were recorded after SARS-CoV-2 infection recovery [57].

- During peak of second wave of COVID-19 disease, some countries especially India and nearby South-Asian countries were getting infected by a rare fungus of mucorales group [59], affecting body surface and internal organs such as brain, sinus, lungs, body tissue, eyes, bones, nerves and can be lethal if not treated and the disease is called black fungus or mucormycosis. During the peak i.e. in month of June 2021, India recorded 28,252 cases of black fungus among which $62.3 \%$ had been exposed to COVID-19 previously and researchers 
revealed that Covid-19 patients are more favourable for this fungus because of humidity and moisture exposure during ventilation in ICU, which favours its growth [60].

\section{Comparison between Spanish flu and covid-19}

Table 2 Comparing Spanish flu and Covid-19

\begin{tabular}{|c|c|c|c|}
\hline $\begin{array}{l}\text { Sr. } \\
\text { No. }\end{array}$ & Variable & 1918 Spanish flu & COVID-19 \\
\hline 1. & $\begin{array}{l}\text { Source of } \\
\text { emergence }\end{array}$ & Wild waterfowl (Anseriformes) [61] & Wild Rhinolophus bat [61] \\
\hline 2. & $\begin{array}{l}\text { Infectious } \\
\text { agent }\end{array}$ & H1N1 Influenza A virus [8] & SARS-CoV-2 [30] \\
\hline 3. & $\begin{array}{l}\text { Origin and } \\
\text { spread }\end{array}$ & $\begin{array}{l}\text { Still uncertain but said to be } \\
\text { originated in the military forts of the } \\
\text { United States [6]. }\end{array}$ & Wuhan, China [29]. \\
\hline 4. & $\begin{array}{l}\text { Age group } \\
\text { affected }\end{array}$ & $\begin{array}{l}\text { Younger populations were severely } \\
\text { affected [62]. }\end{array}$ & Elderly populations were severely affected [63]. \\
\hline 5. & Transmission & $\begin{array}{l}\text { Person-to-person transmission rate } \\
\text { was low, but the infected patients } \\
\text { faced more severe clinical problems } \\
\text { [64]. }\end{array}$ & $\begin{array}{l}\text { Quite high rate of transmission from person to } \\
\text { person, although the clinical problems were } \\
\text { milder [65]. }\end{array}$ \\
\hline 6. & Cell receptor & $\begin{array}{l}\text { Binds to sialic acid receptors that are } \\
\text { found on respiratory epithelial cells } \\
\text { [66]. Within } 10 \text { hours these cells } \\
\text { rupture, releasing approximately } \\
10,000 \text { viruses, each able to infect } \\
\text { other cells. }\end{array}$ & $\begin{array}{l}\text { Infects various cells of respiratory tract, } \\
\text { gastrointestinal enterocytes, arterial and venous } \\
\text { endothelial cells, as well as arterial smooth- } \\
\text { muscle cells, by binding to ACE2 receptors [66]. }\end{array}$ \\
\hline 7. & Symptoms & $\begin{array}{l}\text { Headache, asthenia (weakness), joint } \\
\text { pain, dry cough, high fever, cyanosis, } \\
\text { neurological symptoms, bradycardia, } \\
\text { haemorrhagic fever, primary } \\
\text { influenza pneumonia and secondary } \\
\text { pneumonia bacterial super infections } \\
\text { [67]. }\end{array}$ & $\begin{array}{l}\text { High fever, cough, fatigue, neurological } \\
\text { symptoms, lack of taste and smell, inflammation } \\
\text { of conjunctivae of eye, gastrointestinal } \\
\text { disturbances, and bilateral pneumonia [67]. }\end{array}$ \\
\hline 8. & $\begin{array}{l}\text { Clinical } \\
\text { manifestations }\end{array}$ & $\begin{array}{l}\text { ARDS can develop [68]. Need for } \\
\text { intensive care and mechanical } \\
\text { ventilator support higher [64]. } \\
\text { Tissue damage mostly pulmonary } \\
\text { [70] and pulmonary small-vessel } \\
\text { thrombosis was prominent }[71,72] \text {. } \\
\text { Post mortem findings show severe } \\
\text { pneumonias associated with DAD, } \\
\text { hyaline membrane formation, and } \\
\text { pulmonary edema. Enormous } \\
\text { neutrophilic infiltrates in several } \\
{[74] \text {. }}\end{array}$ & $\begin{array}{l}\text { Lung disease, such as pneumonia or ARDS, } \\
\text { which may ultimately result in progressive } \\
\text { respiratory failure [69]. } \\
\text { Tissue damage in tissues and organ systemically } \\
\text { [70] with neurological complications, and } \\
\text { inflammatory syndromes [61]. Medium and } \\
\text { small-vessel thrombosis reveal in autopsy } \\
\text { studies of patients [73]. } \\
\text { Post mortem findings show DAD including } \\
\text { capillary congestion, pneumocyte necrosis, } \\
\text { interstitial and alveolar edema with widespread } \\
\text { thrombi [69]. Neutrophilic infiltrate infrequent } \\
\text { [75]. }\end{array}$ \\
\hline
\end{tabular}




\begin{tabular}{|c|c|c|c|}
\hline 9. & Complications & $\begin{array}{l}\text { After-effects such as problems with } \\
\text { sleeping, mental distractions, } \\
\text { deafness, blindness, baldness, } \\
\text { secondary bacterial pneumonia. In } \\
\text { some heart problems, lung } \\
\text { tuberculosis and kidney diseases } \\
\text { later in life }[27,28,76] .\end{array}$ & $\begin{array}{l}\text { Not normally linked with secondary bacterial } \\
\text { pneumonia. In some neurological abnormalities, } \\
\text { pulmonary and cardiovascular manifestations, } \\
\text { in some countries fungal infections reported } \\
\text { causing mucormycosis (black fungus) }[60,76] \text {. }\end{array}$ \\
\hline 10. & Mortality & $\begin{array}{l}\text { Mortality rate was statistically } \\
\text { significant higher [64] with high } \\
\text { mortality rate in young adults [77]. } \\
\text { Death occurred after eight days of } \\
\text { illness due to secondary bacterial } \\
\text { infection [79]. }\end{array}$ & $\begin{array}{l}\text { Most deaths occurred in people over age of } 70 \\
\text { years. Young children dying from infection are } \\
\text { infrequent [78]. } \\
\text { Patients died from hyperactive immune } \\
\text { response which resulted in multiple organ } \\
\text { failure [68]. }\end{array}$ \\
\hline 11. & Treatment & $\begin{array}{l}\text { Medical responses inadequate and } \\
\text { people were unaware about the virus } \\
\text { hence no such effective vaccines, } \\
\text { antiviral drugs, or antibiotics } \\
\text { available [80]. }\end{array}$ & $\begin{array}{l}\text { Plasma therapy, ICUs, antibiotic, antiviral, } \\
\text { medical facilities and vaccines are available [56, } \\
61] \text {. }\end{array}$ \\
\hline 12. & Impacts & $\begin{array}{l}\text { Long term negative impacts on social } \\
\text { aspects resulting into decrease in } \\
\text { social trust [81] as well as negative } \\
\text { impacts on economy [82] along with } \\
\text { health of individuals are observed. }\end{array}$ & $\begin{array}{l}\text { Widespread panic situation, negative impacts on } \\
\text { the global economy, affecting international } \\
\text { relations [83]. Mental distress leading to } \\
\text { depression, anxiety and other mental health } \\
\text { issues [84]. Positive impacts appear in } \\
\text { environment such as decrease in pollution } \\
\text { causes improvement in quality of air and water } \\
\text { [85]. }\end{array}$ \\
\hline
\end{tabular}

\section{Conclusion}

COVID-19, due to its high mortality rate and quite high rate of transmission remind us of the first pandemic in the last century the 1918-19 influenza pandemic also known as Spanish Flu. Both are most devastating and lethal pandemics caused due to animal-human interface. Both diseases had shown massive global emergence via silent transmission by the respiratory route or by hands or fomites contaminated with respiratory secretions. Although they are respiratory diseases that can spread from person to person, there are some significant differences in their conditions, clinical course, and preventive measures. Influenza infects primarily by binding to sialic acid receptors that are found on respiratory epithelial cells, whereas SARS-CoV-2 infects various cells of the respiratory tract, gastrointestinal enterocytes, arterial and venous endothelial cells, as well arterial smooth-muscle cells. The speed of replication is much slower in COVID-19 as compared to H1N1, while both the diseases are generally associated with secondary fungal and bacterial infections. The mortality associated with COVID-19 is very different from H1N1, as it affected people with older age while in H1N1 younger populations were mostly affected. During Spanish flu pandemic, the medical knowledge was limited and hence there was unavailability of effective vaccines against the virus but now owing to advanced medical technologies, a large number of vaccines are under development, few of them are already approved and authorized for use. A few positive impacts on environment have been observed due to pandemic status but the negative impacts on physical as well as mental health caused by both the pandemics on lives of people globally remain wounding and irreversible for a long time.

\section{Compliance with ethical standards}

\section{Acknowledgments}

The authors would like to express their gratitude to Ms. Firdos Karim, Department of Zoology, RTM Nagpur University, Nagpur for review of article and helpful comments on this manuscript. 


\section{Disclosure of conflict of interest}

The authors have declared that there is no conflict of interests.

\section{References}

[1] Feinleib M.A Dictionary of Epidemiology, $4^{\text {th }}$ ed. Last JM, Spasoff RA, Harris SS, editors. Am J Epidemiol. 2001; 154(1):93-94.

[2] Mark M. Keep Deadly Virus under Wraps. Savannah Morning News. 2012.

[3] Scerri M, Grech V. WITHDRAWN: The Spanish Flu, COVID-19 and Malta's reactions: Contrasts and similarities. Early Hum Dev. 2020.

[4] Taubenberger JK, Morens DM. 1918 Influenza: The mother of all pandemics. Rev Biomed. 2006; 17(1):69-79.

[5] WHO COVID-19 Emergency Committee highlights need for response efforts over long term. 2020.

[6] Taubenberger JK. The origin and virulence of the 1918 "Spanish" influenza virus. Proc Am Philos Soc. 2006; 150(1):86-112.

[7] Lyngdoh M. The parallels between COVID-19 and the Spanish flu of 1918. Int J community Med Public Health. 2020; 7(11):4687-4689.

[8] Kanegae Y, Sugita S, Shortridge KF, Yoshioka Y, Nerome K. Origin and evolutionary pathways of the H1 hemagglutinin gene of avian, swine and human influenza viruses: co-circulation of two distinct lineages of swine virus. Arch Virol. 1994; 134:17-28.

[9] Patterson KD, Pyle GF. The Geography and Mortality of the 1918-1919 Influenza Pandemic. Bull Hist Med. 1991; 65(1):4-21.

[10] Britannica T. Editors of Encyclopaedia. Influenza pandemic of 1918-19. Encyclopedia Britannica. 2020.

[11] Palese P. The great influenza the epic story of the deadliest plague in history. J Clin Invest. 2004; 114(2):146.

[12] Barry JM. The site of origin of the 1918 influenza pandemic and its public health implications. J Transl Med. 2004; 2:3.

[13] Oxford JS. The so-called Great Spanish Influenza Pandemic of 1918 may have originated in France in 1916. Philosophical transactions of the Royal Society of London. Series B, Biological sciences. 2001; 356(1416):18571859.

[14] Conenello GM, Zamarin D, Perrone LA, Tumpey T, Palese P. A single mutation in the PB1-F2 of H5N1 (HK/97) and 1918 influenza A viruses contributes to increased virulence. PLoS Pathog. 2007; 3(10):1414 -1421.

[15] Kobasa D, Takada A, Shinya K, Hatta M, Halfmann P, Theriault S. et al. Enhanced virulence of influenza A viruses with the haemagglutinin of the 1918 pandemic virus. Nature. 2004; 431: 703-707.

[16] Tumpey TM, Basler CF, Aguilar PV, Zeng H, Solorzano A, Swayne DE, et al. Characterization of the reconstructed 1918 Spanish influenza pandemic virus. Science. 2005; 310(5745):77-80.

[17] Pappas C, Aguilar PV, Basler CF, Solorzano A, Zeng H, Perrone LA, et al. Single gene reassortants identify a critical role for PB1, HA, and NA in the high virulence of the 1918 pandemic influenza virus. Proc Natl Acad Sci U. S. A. 2008; 105(8):3064-3069.

[18] Vernon K, Julius AK. "Influenza Viruses," chap. 6 of Vernon Knight, M.D., ed., Viral and Mycoplasmal Infections of the Respiratory Tract Philadelphia: Lea \&Febiger. 1973; p.99.

[19] Victor CV. A Doctor's Memories Indianapolis: Bobbs-Merrill Co. 1926; p.416-17.

[20] Jester BJ, Uyeki TM, Patel A, Koonin L, Jernigan DB. 100 Years of Medical Countermeasures and Pandemic Influenza Preparedness. Am J Public Health. 2018; 108(11):1469-1472.

[21] Killingley B, Nguyen-Van-Tam J. Routes of influenza transmission. Influenza Other Respir Viruses. 2013; 72(2):42-51.

[22] Jordan D, Tumpey T, Jester B. The Deadliest Flu: The Complete Story of the Discovery and Reconstruction of the 1918 Pandemic Virus. CDC. 2019.

[23] Jordan EO. Epidemic Influenza: A Survey. Chicago, American Medical Association. 1927. 
[24] Erkoreka A. Origins of the Spanish Influenza Pandemic (1918-1920) and its relation to the First World War. J Mol Genet Med. 2009; 3(2):190-194.

[25] Ansart S, Pelat C, Boelle PY et al. Mortality Burden of the 1918-1919 Influenza Pandemic in Europe. Influenza Other Respir Viruses. 2009; 3(3):99-106.

[26] Mamelund SE. Influenza, Historical. International Encyclopedia of Public Health. 1st ed. 2008; 3:p.597-609.

[27] Mamelund SE. The diffusion of influenza in Norway during the 1918-19 Pandemic. Nor J Epidemiol. 1998; 8:4558.

[28] Collier R. The Plague of the Spanish Lady. The influenza Pandemic of 1918-1919. London: Macmillan. 1974.

[29] Siddiqui AF, Wiederkehr M, Rozanova L, Flahault A. Situation of India in the COVID-19 Pandemic: India's Initial Pandemic Experience. Int J Environ Res Public Health. 2020; 17(23):8994.

[30] Mundhada S, Tanna J, Singha B, Nayak AR, Husain AA, Raje DV, et al. Incidence and Epidemiological study of COVID-19 in Nagpur urban region (India) using Molecular testing. medRxiv. 2021; 21256719.

[31] Perlman S, Netland J. Coronavirus Post-SARS: Update on Replication and Pathogenesis. Nat Rev Microbiol. 2009; 7(6):439-450.

[32] Sheahan TP, Sims AC, Zhou S, Graham RL, Pruijssers AJ, Agostini ML, et al. An orally bioavailable broad-spectrum antiviral inhibits SARS-CoV-2 in human airway epithelial cell cultures and multiple coronaviruses in mice. Sci Transl Med. 2020; 12(541):eabb5883.

[33] Mao L, Jin H, Wang M, Hu Y, Chen S, He Q et al. Neurologic Manifestations of Hospitalized Patients With Coronavirus Disease 2019 in Wuhan, China. JAMA Neurol. 2020; 77(6):683-690.

[34] World Health Organization Coronavirus Disease 2019 (COVID-19) Situation Report-94; 2020.

[35] Wu YC, Chen CS, Chan YJ. The outbreak of COVID-19: An overview. J Chin Med Assoc. 2020; 83(3):217-220.

[36] Di Gennaro F, Pizzol D, Marotta C, Antunes M, Racalbuto V, Veronese N. Coronavirus Diseases (COVID-19) Current Status and Future Perspectives: A Narrative Review. Int J Environ Res Public Health. 2020; 17(8):2690.

[37] Zu ZY, Jiang MD, Xu PP, Chen W, Ni QQ, Lu GM, et al. Coronavirus Disease 2019 (COVID-19): A Perspective from China. Radiology. 2020; 296(2):E15-E25.

[38] Khan S, Siddique R, Shereen MA, Ali A, Liu J, Bai Q, et al. Emergence of a Novel Coronavirus, Severe Acute Respiratory Syndrome Coronavirus 2: Biology and Therapeutic Options. J Clin Microbiol. 2020; 58(5):e0018720.

[39] Lahiri D, Ardila A. COVID-19 Pandemic: A Neurological Perspective. Cureus. 2020; 12(4):e7889

[40] WHO Weekly epidemiological update on COVID-19 - 14 September 2021.

[41] Weekly epidemiological update on COVID-19 - 19 October 2021 Edition.

[42] WHO Coronavirus (COVID-19) Dashboard. 2020.

[43] Ouassou H, Kharchoufa L, Bouhrim M, Daoudi NE, Imtara H, Bencheikh N, et al. The Pathogenesis of Coronavirus Disease 2019 (COVID-19): Evaluation and Prevention. J Immunol Res. 2020; 1-7.

[44] Satarker S, Nampoothiri M. Structural Proteins in Severe Acute Respiratory Syndrome Coronavirus-2. Arch Med Res. 2020; 51(6):482-491.

[45] Ghosh R. An Introduction of Corona Virus along with its Transmission \& Managements. IJSR. 2020; 9(5):527-534.

[46] Wiersinga WJ, Rhodes A, Cheng AC, Peacock SJ, Prescott HC. Pathophysiology, Transmission, Diagnosis, and Treatment of Coronavirus Disease 2019 (COVID-19): A Review. JAMA. 2020; 324(8):782-793.

[47] Cascella M, Rajnik M, Aleem A, Dulebohn SC, Di Napoli R. Features, Evaluation, and Treatment of Corona virus (COVID-19). StatPearls. 2021.

[48] Vieira JM, Ricardo OMP, Hannas CM, Kanadani TCM, Prata TDS, Kanadani FN. What do we know about COVID-19? A review article. Rev Assoc Med Bras (1992). 2020; 66(4):534-540.

[49] World Health Organization. Coronavirus disease 2019 (COVID-19): situation report. 2020; 73.

[50] Li Y, Zhao R, Zheng S, Chen X, Wang J, Sheng X, et al. Lack of Vertical Transmission of Severe Acute Respiratory Syndrome Coronavirus 2, China. Emerg Infect Dis. 2020; 26(6):1335-1336. 
[51] Linton NM, Kobayashi T, Yang Y, Hayashi K, Akhmetzhanov AR, Yuan B, et al. Incubation Period and Other Epidemiological Characteristics of 2019 Novel Coronavirus Infections with Right Truncation: A Statistical Analysis of Publicly Available Case Data. J Clin Med. 2020; 9(2):538.

[52] Lauer SA, Grantz KH, Bi Q, Jones FK, Zheng Q, Meredith HR, et al. The Incubation Period of Coronavirus Disease 2019 (COVID-19) From Publicly Reported Confirmed Cases: Estimation and Application. Ann Intern Med. 2020; 172(9):577-582.

[53] Beltrán-Corbellini Á, Chico-García JL, Martínez-Poles J, Rodríguez-Jorge F, Natera-Villalba E, Gómez-Corral J, et al. Acute-onset smell and taste disorders in the context of COVID-19: a pilot multicentre polymerase chain reaction based case-control study. Eur J Neurol. 2020; 27(9):1738-1741.

[54] Wang C, Wang Z, Wang G, Lau JY, Zhang K, Li W. COVID-19 in early 2021: current status and looking forward. Signal Transduct Target Ther. 2021; 6(1):114.

[55] Bryant A, Lawrie TA, Dowswell T, Fordham EJ, Mitchell S, Hill SR, et al. Ivermectin for Prevention and Treatment of COVID-19 Infection: A Systematic Review, Meta-analysis, and Trial Sequential Analysis to Inform Clinical Guidelines. Am J Ther. 2021; 28(4):e434-e460.

[56] NY Times Corona Vaccine Tracker. 2021.

[57] Lopez-Leon S, Wegman-Ostrosky T, Perelman C, Sepulveda R, Rebolledo PA, Cuapio A, et al. More than 50 Longterm effects of COVID-19: a systematic review and meta-analysis. Sci Rep. 2021; 11(1):16144.

[58] Del Rio C, Collins LF, Malani P. Long-term Health Consequences of COVID-19. JAMA. 2020; 324(17):1723-1724.

[59] Jeong W, Keighley C, Wolfe R, Lee WL, Slavin MA, Kong DCM, et al. The epidemiology and clinical manifestations of mucormycosis: a systematic review and meta-analysis of case reports. Clin Microbiol Infect. 2019; 25(1):2634.

[60] Moona AA, Islam MR. Mucormycosis or black fungus is a new fright in India during covid-19 pandemic: Associated risk factors and actionable items. Public Health Pract (Oxf). 2021; 2:100153.

[61] Morens DM, Taubenberger JK, Fauci AS. A Centenary Tale of Two Pandemics: the 1918 influenza pandemic and COVID-19, Part I. Am J Public Health. 2021; 111(6):1086-1094.

[62] Reed C, Chaves SS, Perez A, D’Mello T, Kirley PD, Aragon D, et al. Complications among adults hospitalized with influenza: a comparison of seasonal influenza and the 2009 H1N1 pandemic. Clin Infect Dis. 2014; 59(2):166-74.

[63] Verity R, Okell LC, Dorigatti I, Winskill P, Whittaker C, Imai N, et al. Estimates of the severity of corona virus disease 2019: a model-based analysis. Lancet Infect Dis. 2020; 20(6):669-77.

[64] Dawood FS, Iuliano AD, Reed C , Meltzer MI, Shay DK, Cheng PY, et al .Estimated global mortality associated with the first 12 months of 2009 pandemic influenza A H1N1 virus circulation: a modelling study. Lancet Infect Dis. 2012; 12(9):687-95.

[65] Li LQ, Wang YQ ,Wang ZP ,Liang Y, Huang TB, Zhang HY, et al. COVID-19 patients' clinical characteristics, discharge rate, and fatality rate of meta-analysis. J Med Virol. 2020; 92(6):577-583.

[66] Wang Q, Zhang Y, Wu L, Niu S, Song C, Zhang Z, et al. Structural and functional basis of SARS-CoV-2 entry by using human ACE2. Cell. 2020; 181(4):894-904.

[67] Tornali C, Vecchio FAG, Vecchio I. Spanish Flu and Covid-19: Historical Correlations and Bioethical Implications. J Clin Research Bioeth. 2020; 11(3):352.

[68] Wu YC, Chen CS, Chan YJ. The outbreak of COVID-19. J Chin Med Assoc. 2020; 83(3):217-20.

[69] Carsana L, Sonzogni A, Nasr A, Rossi RS, Pellegrinelli A, Zerbi P, et al. Pulmonary post-mortem findings in a series of COVID-19 cases from northern Italy: a two-centre descriptive study. Lancet Infect Dis. 2020; 20(10):1135-40.

[70] Rapkiewicz AV, Mai X, Carsons SE, Pittaluga S, Kleiner DE, Berger JS, et al. Megakaryocytes and platelet-fibrin thrombi characterize multi-organ thrombosis at autopsy in COVID-19: A case series. E clinical Medicine. 2020; 24:100434.

[71] LeCount ER. Disseminated necrosis of the pulmonary capillaries in influenza pneumonia. JAMA. 1919; 72(21):1519-1520. 
[72] Walters KA, D’Agnillo F, Sheng ZM, Kindrachuk J, Schwartzman LM, Kuestner RE, et al. 1918 pandemic influenza virus and Streptococcus pneumonia co-infection results in activation of coagulation and widespread pulmonary thrombosis in mice and humans. J Pathol. 2016; 238(1):85-97.

[73] Fox SE, Akmatbekov A, Harbert JL, Li G, Quincy Brown J, Vander Heide RS. Pulmonary and cardiac pathology in African American patients with COVID-19: an autopsy series from New Orleans. Lancet Respir Med. 2020; 8(7):681-686.

[74] Sheng ZM, Chertow DS, Ambroggio X, McCall S, Przygodzki RM, Cunningham RE, et al. Autopsy series of 68 cases dying before and during the 1918 influenza pandemic peak. Proc Natl Acad Sci USA. 2011; 108(39):1641616421.

[75] Sauter JL, Baine MK, Butnor KJ, Buonocore DJ, Chang JC, Jungbluth AA, et al. Insights into pathogenesis of fatal COVID-19 pneumonia from histopathology with immunohistochemical and viral RNA studies. Histopathology. 2020; 77(6):915-925.

[76] Chen LYC, Quach TTT. COVID-19 cytokine storm syndrome: a threshold concept. Lancet Microbe. 2021; 2(2):4950 .

[77] Taubenberger JK, Kash JC, Morens DM. The 1918 influenza pandemic: 100 years of questions answered and unanswered. Sci Transl Med. 2019; 11(502):eaau5485.

[78] King PT, Londrigan SL. The 1918 influenza and COVID-19 pandemics: The effect of age on outcomes. Respirology. 2021; 26(9):840-841.

[79] Anne AO. Bacterial Pneumonia Caused Most Deaths in 1918 Influenza Pandemic. Int J Health Sci. 2008; 154:152155.

[80] Beach B, Clay K, Saavedra MH. The 1918 influenza pandemic and its lessons for Covid-19. NBER. 2020.

[81] Assave A, Alfani G, Gandolfi F, Le Moglie M. Epidemics and trust: The case of the Spanish Flu. Health Economics. 2021; 30(4):840-857.

[82] James B. Economics Effects of Spanish Flu. Reserve Bank of Australia. Bulletin-June 2020.

[83] Liang ST, Liang LT, Rosen JM. COVID-19: a comparison to the 1918 influenza and how we can defeat it. Postgrad Med J. 2021; 97(1147):273-274.

[84] Schafer SK, Sopp MR, Schanz CG, Staginnus M, Göritz AS, Michael T. Impact of COVID-19 on Public Mental Health and the Buffering Effect of a Sense of Coherence. Psychother Psychosom. 2020; 89(6):386-392.

[85] Khan I, Shah D, Shah SS. COVID-19 pandemic and its positive impacts on environment: an updated review. Int J Environ Sci Technol (Tehran). 2020; 1-10. 